\title{
SISTEM PENGOLAHAN DATA PEMESAN/BOOKERS TIKET PESAWAT PADA PT KINDAI PERMATA LAMPUNG
}

\section{RONNY SAPUTRA}

\begin{abstract}
PT Kindai Permata Lampung yang bergerak dibidang penjualan dan pemasaran tiket pesawat seperti perusahaan lain pada umumnya, sudah menggunakan komputer dan teknologinya untuk menunjang kegiatan operasionalnya sekaligus digunakan untuk meningkatkan efektifitas kerja, dengan teknologi komputer suatu perusahaan diharapkan mampu terus bersaing dalam meningkatkan kualitasnya. Komputer merupakan salah satu sarana yang berperan penting dalam melakukan aktivitas sehari-hari pada sebuah perusahaan, baik itu aktivitas manajerial maupun operasional. Pengolahan data pemesan tiket PT Kindai Permata Lampung masih memanfaatkan Ms Access untuk mengolah data pemesan tiket dan laporan penjualannya, hal tersebutlah yang masih menjadi kendala, karena dalam pengoperasiannya menu-menu built-in yang terdapat pada Ms Access, dapat mempersulit pengguna dikarenakan kurang mudah digunakan tidak (user friendly).Penulis ingin membangun suatu sistem dengan menggunakan bahasa pemrograman Visual Basic 6.0, dengan memiliki tampilan menarik, mudah digunakan dan pengaksesan data disajikan dalam bentuk yang lebih komunikatif, sistem pengolahan data pemesan tiket atau aplikasi database yang dihasilkan diharapkan mampu menjadi salah satu sumber daya dalam perusahaan yang digunakan untuk mentransformasikan data menjadi informasi.Penulis menyimpulkan bahwa pada PT Kindai Permata Lampung masih bersifat semi komputer, kesulitan dalam pencarian data hasil transaksi, dan laporan yang kurang terperinci. Penulis menyarankan agar kedepannya dapat menerapkan sistem pemesan tiket yang teraplikasi dengan baik dan keamanan data dapat lebih terjamin dan informasi laporan dapat lebih jelas dan terperinci.
\end{abstract}

Keywords: Tiket,Bahasa Pemrograman,Database.

\section{PENDAHULUAN}

\subsection{Latar Belakang}

PT Kindai Permata Lampung yang bergerak dibidang penjualan dan pemasaran tiket pesawat seperti perusahaan lain pada umumnya, sudah menggunakan komputer dan teknologinya untuk menunjang kegiatan operasionalnya sekaligus digunakan untuk meningkatkan efektifitas kerja, dengan teknologi komputer suatu perusahaan diharapkan mampu terus bersaing dalam meningkatkan kualitasnya.

\subsection{Perumusan Masalah}

Berdasarkan Latar Belakang yang telah dipaparkan, maka dapat dirumuskan masalahnya adalah :

1. Bagaimana analisa dan rancangan Sistem Pengolahan Data yang berupa aplikasi database pemesan/bookers tiket pesawat pada PT Kindai Permata Lampung.

2. Bagaimana mewujudkan aplikasi database yang memiliki tampilan menarik, mudah digunakan dan pengaksesan data disajikan dalam bentuk yang komunikatif.

\subsection{Tujuan Penelitian}

Penelitian ini dilakukan dengan tujuan sebagai berikut
1. Membangun sistem informasi baru dengan mengembangkan sistem yang ada menjadi sistem informasi yang lebih baik.

2. Menganalisa dan Merancang Sistem Pengolahan Data yang berupa aplikasi database pemesan tiket pesawat pada PT Kindai Permata Lampung.

3. Membangun Sistem Pengolahan Data yang berupa aplikasi database yang memiliki tampilan menarik, mudah digunakan dan pengaksesan data disajikan dalam bentuk yang komunikatif.

4. Mengukur sejauh mana daya serap mahasiswa dalam menerima dan menerapkan teori yang diperoleh selama di kampus.

\subsection{ManfaatPenelitian}

Manfaat yang penulis harapkan dari penelitian ini adalah :

1. Teoritis diharapkan dapat digunakan sebagai bahan untuk memperluas pengetahuan dan kemampuan dalam bidang pengolahan data.

2. Praktis diharapkan aplikasi database yang dihasilkan dapat menjadi salah satu komponen yang melengkapi sistem informasi pada PT Kindai Permata Lampung. 


\section{TINJAUAN PUSTAKA Pengertian Sistem}

Terdapat dua kelompok pendekatan di dalam mendefinisikan sistem, yaitu yang menekankan pada prosedurnya dan yang menekankan pada komponennya atau elemennya. Pendekatan sistem yang lebih menekankan pada prosedur mendefinisikan sistem sebagai berikut : Pendekatan sistem yang menekankan pada prosedur, Jogiyanto (2001:1) mengemukakan, "Suatu sistem adalah suatu jaringan kerja dan prosedur yang saling berhubungan berkumpul bersama-sama untuk melakukan suatu kegiatan atau menyelesaikan suatu sasaran yang tertentu".

\section{Karakteristik}

Sistem

Sistem mempunyai karakteristik atau sifat - sifat yang tertentu yaitu sebagai berikut :

\section{Komponen Sistem ( Component System )}

Sistem terdiri dari sejumlah komponen yang saling berinteraksi, yang artinya saling bekerjasama membentuk satu kesatuan. Komponen - komponen sistem atau elemen - elemen dapat berupa suatu subsistem atau bagian - bagian sistem.

2. Batas Sistem (Boundary System )

Batas sistem merupakan daerah yang membatasi antara suatu sistem dengan sistem yang lainnya atau dengan lingkungan luarnya. Batas sistem ini memungkinkan suatu sistem dipandang sebagai satu kesatuan. Batas sistem menunjukkan ruang lingkup dari sistem tersebut.

3. Lingkungan luar sistem ( Environments System )

Lingkungan luar dari suatu sistem adalah apapun diluar batas dari sistem yang mempengaruhi operasi sistem. Lingkungan luar sistem dapat bersifat menguntungkan dan dapat juga bersifat merugikan sistem tersebut.

4. Penghubung sistem (Interface System )

Penghubung merupakan media penghubung antara satu subsistem dengan subsistem yang lainnya.

5. Masukan sistem (Input System )

Masukan adalah energi yang dimasukan ke dalam sistem. Masukan dapat berupa masukan perawatan dan masukan sinyal.

\subsection{Klasifikasi Sistem}

Sistem dapat diklasifikasikan dari beberapa sudut pandang, antaranya adalah sebagai berikut ini :
1. Sistem diklasifikasikan sebagai sistem abstrak dan sistem fisik.

Sistem abstrak adalah sistem yang berupa pemikiran atau ide - ide yang tidak tampak secara fisik. Sistem fisik merupakan sistem yang ada secara fisik.

2. Sistem diklasifikasikan sebagai sistem alamiah dan sistem buatan manusia.

Sistem alamiah adalah sistem yang terjadi melalui proses alam, tidak dibuat manusia. Sistem buatan manusia adalah sistem yang dirancang oleh manusia.

3. Sistem diklasifikasikan sebagai sistem tertentu dan sistem tak tertentu.

Sistem tertentu adalah sistem yang kondisi masa depannya dapat diprediksi. Sistem tak tertentu adalah sistem yang kondisi masa depannya tidak dapat diprediksi karena mengandung unsur probabilitas.

4. Sistem diklasifikasikan sebagai sistem tertutup dan sistem terbuka.

Sistem tertutup merupakan sistem yang tidak berhubungan dan tidak terpengaruh dengan lingkungan luarnya. Sistem terbuka adalah sistem yang berhubungan dan terpengaruh dengan lingkungan luarnya.

\subsection{Komponen Sistem}

Komponen sistem terdiri dari sejumlah komponen yang saling beinteraksi, yang artinya saling bekerjasama membentuk suatu kesatuan. Komponen sistem atau elemen-elemen sistem dapat berupa suatu sub sistem atau bagian dari sistem. Suatu sistem dapat mempunyai suatu sistem yang lebih besar yang disebut dengan supra sistem. Komponen-komponen sistem tersebut terdiri dari:

1. Masukan Sistem (Input Block)

2. Masukan atau input adalah data yang dimasukkan kedalam sistem informasi beserta mode dan media yang digunakan untuk menangkap dan memasukkan data tersebut kedalam sistem. Blok Model ( Model Block)

Blok model terdiri dari kombinasi prosedur logika dan model matematika atau logica matematical mode yang akan memperluas dan mengolah data masukan dan data yang tersimpan dibasis data dengan cara tertentu untuk menghasilkan keluaran yang dikehendaki.

3. Blok Keluaran ( Output Block) 
Prosedur dari suatu sistem informasi adalah keluaran atau output yang merupakan informasi yang berkualitas dan dokumentasi yang berguna untuk semua tingkat manajemen dan semua pemakai sistem.

4. Blok Teknologi ( Technology Block)

Teknologi ibarat mesin untuk menjalankan sistem informasi atau kotak alat (tool box) dalam sistem informasi. Teknologi digunakan untuk menerima masukan, menjalankan model, menyimpan dan membantu pengendalian sistem secara keseluruhan.

5. Blok Basis Data (Database Block)

6. Basis data merupakan tempat menyimpan data yang digunakan untuk melayani kebutuhan pemakai informasi. Basis data merupakan kumpulan data yang saling berhubungan satu dengan yang lainnya, tersimpan diperangkat keras dan digunakan perangkat lunak untuk memanipulasinya. Blok Pengendalian ( Control Block)

Semua sistem informasi harus dilindungi dari bencana dan ancaman seperti bencana alam, api, kecurangan, kegagalan sistem, kesalahan dan penggelapan, penyadapan ketidakefisienan dan sebagainya.

\section{Perencanaan Sistem}

Perencanaan sistem ini menyangkut estimasi dari kebutuhan - kebutuhan fisik, tenaga kerja, dan dana yang dibutuhkan untuk mendukung pengembangan sistem ini serta untuk mendukung operasinya setelah diterapkan.

\section{Analisis Sistem}

Analisis sistem dapat didefinisikan sebagai penguraian dari suatu sistem informasi yang utuh ke dalam bagian - bagian komponennya dengan maksud untuk mengidentifikasikan dan mengevaluasi permasalahan - permasalahan, kesempatan - kesempatan, hambatan - hambatan yang terjadi dan kebutuhan - kebutuhan yang diharapkan sehingga dapat diusulkan perbaikan perbaikannya.

Desain Sistem

Desain sistem dapat diartikan sebagai berikut :

1. Tahap setelah analisis dari siklus pengembangan sistem

2. Persiapan untuk rancang bangun implementasi

3. Menggambarkan bagaimana suatu sistem dibentuk
4. Pendefinisian dari kebutuhan - kebutuhan fungsional

\subsection{Pengertian Data}

Menurut Ir. Fathansyah (2002:2) data adalah representasi fakta dunia nyata yang mewakili suatu objek seperti manusia (pegawai, siswa, pembeli, pelanggan), barang, hewan, peristiwa, konsep, keadaan, dan sebagainya, yang direkam dalam bentuk angka, huruf, simbol, teks, gambar, bunyi, atau kombinasi.

\subsection{Pengertian Pengolahan data}

Pemrosesan data mencakup pengumpulan data, mentransformasikan ke dalam informasi dan penyebaran informasi tersebut.

Pengumpulan data terdiri dari :

1. Data dikumpulkan dan dimasukkan kedalam sistem.

2. Data diproses untuk menciptakan informasi.

3. Informasi disampaikan keluaran dari sistem.

\section{Kamus Data}

Kamus data adalah katalog fakta tentang data dan kebutuhan - kebutahan informasi dari suatu sistem informasi, dengan kamus data analis sistem dapat mendefinisikan data yang mengalir di sistem dengan lengkap.

\section{Data Flow Diagram (DFD)}

Data Flow Diagram (DFD) merupakan alat yang digunakan pada metodologi pengembangan sistem yang tertruktur. Beberapa simbol digunakan di Data Flow Diagram (DFD) adalah sebagai berikut : External entitity (kesatuan luar) atau boundary (batas sistem) Kesatuan luar ini kebanyakan adalah salah satu dari berikut ini :

1. Kantor, departemen atau divisi dalam perusahaan tetapi diluar sistem yang sedang dikembangkan

2. Orang atau sekelompok orang di organisasi tetapi di luar sistem yang sedang di kembangkan

3. Organisasi atau oarang yang berada di luar organisasi seperti langganan, pemasok

4. Sistem informasi yang lain diluar sistem yang sedang dikembangkan

5. Sumber asli dari suatu transaksi

6. Penerima akhir dari suatu laporan yang dihasilkan oleh sistem.

Bagan Alir Sistem Atau Dokumen (Flowchart) Bagan alir sistem merupakan bagan yang menunjukan arus pekerjaan secara keseluruhan dari 
sistem dan menjelaskan urut - urutan dari prosedur - prosedur yang ada di dalam sistem dan menunjukan apa yang dikerjakan di sistem.

\section{Entity Relational Diagram (ERD)}

Teknik Entity Relational, gambaran dunia nyata diistilahkan dalam objek dan relasinya yang digunakan untuk mengembangkan inisial dari desain basis data. Teknik Entity Relational menggunakan entity dan atribut. Entity adalah objek yang mempunyai eksistensi dan tedefinisi dengan baik.

\section{Microsoft Visual Basic 6.0}

Visual Basic adalah 6.0 salah satu bahasa pemrograman untuk membuat program aplikasi dalam lingkungan windows. Mengembangkan aplikasi VB menggunakan pendekatan visual ( $G U I$ - Grapichal User Interface ) untuk merancang antarmuka interface.

\section{Menu Bar}

Berisi menu-menu utama Visual Basic 6.0. Misalnya menu untuk mengolah file [file], menu untuk pengeditan [Edit], menu untuk mengatur tampilan [View]. Di menu-menu tersebut terdapt sub - sub menu.

\section{Main Toolbar}

Berisi icon-icon untuk menjalankan sesuai perintah/tugas secara cepat.

\section{Project Explorer Windows}

Jendela untuk menampilkan daftar form dan modul projek yang sedang dibuat. Projek merupakan kumpulan dari modul form, modul class, file yang membangun program aplikasi.

\section{Properties Windows}

Berisi daftar untuk (men-setting) properti objek yang sedang aktif. Kotak pada bagian atas berisi semua objek yang ada. Ada dua pilihan tampilan, yaitu: Alphabetic (urut abjad) dan Catagorized (urut berdasarkan kelompok).

\section{Form Layout Windows}

Jendela yang menunjukkan posisi relatif form terhadap layar monitor.

\section{Form Designer}

Jendela untuk merancang aplikasi yang sedang dibuat. Form designer ibarat 'kanvas' untuk 'melukis' user interface.

\section{Code Editor Windows}

Merupakan tempat untuk menuliskan coding. Salah satu jendela yang sangat penting dan akan paling sering dipakai pada saat merncang user interface yaitu Tool Box.

\section{Picture Box}

Objek kontrol yang digunakan untuk menampilkan gambar (image) dengan format BMP.ICO (icon),WWF (metafile), GIF, JPEG, DIB (Bitmap), CUR (cursor, dan EMF (enhanced metafile).

\section{Label}

Objek kontrol yang digunakan untuk menampilkan teks yang tetap dan tidak dapat diubah oleh pemakai (user) Textbox Objek kontrol yang digunakan untuk menampung kata (string) yang dimasukan oleh pemakai.

\section{Frame}

Kontrol yang berfungsi untuk menampung kontrolkontrol lainnya dalam satu kelompok.

\section{CommandButton}

Kontrol tombol perintah yang berfungsi untuk membangkitkan kejadian (event) tertentu ketika user melakukan klik padanya.

\section{Checkbox}

Memasukan pilihan yang isinya ya / tidak, yes / no, benar / salah, true / false.

\section{Optionbutton}

Memasukkan pilihan yang memungkinkan user memilih lebih dari satu pilihan.

\section{ListBox}

Untuk menampung sejumlah item dan user dapat memilih lebih dari satu (bergantung pada propertyMultySelect).

\section{ComboBox}

Kombinasi dari TextBox dan ListBox dimana pemasukan data dapat dilakukan dengan pemilihan atau pengetikan langsung.

\section{HscrollBar dan VscrollBar}

Untuk membentuk scroll yang berdiri sendiri. 
Timer

Kontrol waktu yang berfungsi untuk proses background yang diaktifkan berdasarkan interval waktu tertentu.

DriveListBox, DirListBox, dan FileListBox Membuat kotak dialog yang berkaitan dengan file / folder.

\section{Shape dan Line}

Membuat bentuk seperti garis, persegi, bulatan, oval dan lain-lain.

\section{Image}

Fungsinya menyerupai PictureBox namun tidak dapat digunakan untuk menampung kontrol lainnya. Kontrol Image menggunakan sumber daya yang lebih kecil daripada PictureBox. Data digunakan untuk pengaksesan database.

\section{OLE ( Object Lingking and Embedding )}

Berfungsi untuk menjalankan progarm aplikasi windows yang lain kedalam program aplikasi yang kita buat.

\section{Microsoft Database Access}

Microsoft Acces suatu aplikasi yang dapat membantu kita membuat sebuah aplikasi database dalam waktu yang relatif singkat. Biasanya digunakan untuk pembuatan aplikasi-aplikasi yang kecil tampilannya dapat dilihat pada gambar 2.13. berikut ini :

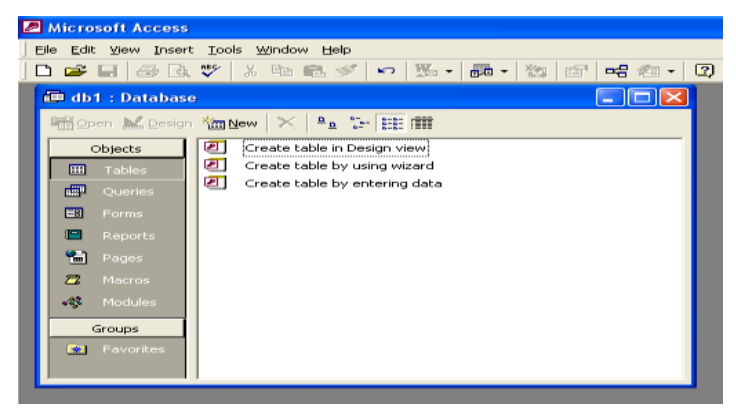

Gambar 2. 13. Tampilan dasar Microsoft Access Komponen-komponen pada Microsoft Access
a. Table
Table digunakan untuk menyimpan data.
b. Query
Query digunakan untuk memanipulasi data.

\section{c. Form}

Form digunakan untuk frontend aplikasi. Biasanya untuk menampilkan data, menambahkan data dan lain-lain.

\section{d. Report}

Report digunakan untuk membuat laporan.

\section{e. Macro}

Macro digunakan untuk melakukan satu atau beberapa fungsi.

\section{f. Switchboard}

3.5 Switchboard digunakan untuk tampilan menu utama.

\section{ANALISIS DAN PERANCANGAN SISTEM Analisis Sistem (System Analysis)}

Tahap analisis sistem adalah tahap penguraian dari suatu sistem yang utuh ke dalam bagian-bagian komponennya dengan maksud untuk mengidentifikasikan dan mengevaluasi permasalahan-permasalahan, hambatan-hambatan yang terjadi serta kebutuhan-kebutuhan yang diharapkan dapat dibuat rancangan sistem baru yang sesuai dengan kebutuhan.

\section{Analisa Permasalahan}

Berdasarkan penelitian yang dilakukan maka permasalahan dapat diidentifikasi sebagai berikut : Bagaimana analisa dan rancangan Sistem Pengolahan Data yang berupa aplikasi database pemesan/bookers tiket pesawat pada PT Kindai Permata Lampung. Bagaimana mewujudkan aplikasi database yang memiliki tampilan menarik, mudah digunakan dan pengaksesan data disajikan dalam bentuk yang komunikatif.

\section{Metode Pengembangan Sistem}

Metode pengembangan sistem yang digunakan penulis dalam penelitian ini adalah metode rancangan Sistem Pengolahan Data dengan menggunakan Sistem Waterfall yang berupa aplikasi database pemesan/bookers tiket pesawat pada

PT Kindai Permata Lampung. Tahap-tahapannya adalah sebagai berikut :

\section{Tahap Perencanaan (Planning)}

Tahap ini, tim pembuat sistem mencoba memahami permasalahan yang muncul dan 
mendefinisikannya secara rinci, kemudian menentukan tujuan pembuatan sistem dan mengidentifikasikan kendala-kendalanya.

\section{Tahap Analisis}

Tahap ini, tim pembuat sistem akan menganalisis permasalahan secara lebih mendalam dengan menyusun suatu studi kelayakan yaitu antara lain menganalisis mengenai sistem pesan tiket, sistem record data pemesan, sistem penjualan dan pelaporan data transaksi.

\section{Tahap Perancangan}

Memahami sistem sebelumnya dan kriteria-kriteria sistem yang akan dibangun, tim pembuat dapat membuat rancangan sistem informasi terlebih dahulu.

\section{Tahap Penerapan}

\begin{abstract}
Merupakan kegiatan untuk mengimplementasikan rancangan yang telah disusun agar dapat diwujudkan. Proses implementasi untuk prosedur dalam teknologi komputer akan menggunakan bahasa komputer. Pertimbangan memilih bahasa komputer didasarkan pada dua hal yaitu kemampuan bahasa itu untuk menangani dan mengimplementasikan proses-proses yang dirancang.
\end{abstract}

\section{Tahap Evaluasi}

Tahap ini, dilakukan uji coba sistem yang telah selesai disusun. Proses uji coba ini dilakukan untuk memastikan bahwa sistem tersebut sudah benar, sesuai karakteristik yang diterapkan dan tidak ada kesalahan-kesalahan yang terkandung didalamnya.

\section{Tahap Penggunaan dan Pemeliharaan}

Sistem yang telah diuji dan dinyatakan lolos dapat mulai digunakan untuk menangani prosedur bisnis yang sesungguhnya. Selama sistem digunakan, tim teknis harus memperhatikan masalah pemeliharaan sistem.

\section{Perancangan Sistem \\ Data Flow Diagram (DFD)}

Data Flow Diagram (DFD) adalah suatu model logika/proses yang dibuat untuk menggambarkan dimana asal data dan kemana tujuan data yang keluar dari sistem, dimana data disimpan, proses apa yang menghasilkan hubungan antara data pada sistem dan proses pada sistem atau merupakan model dari sistem untuk menggambarkan pembagian sistem ke modul yang lebih kecil.
Diagram

Konteks

Diagram konteks adalah sebuah diagram yang terdiri dari suatu proses dan menggambarkan ruang lingkup suatu sistem. Diagran konteks merupakan level tertinggi dari DFD yang menggambarkan seluruh input ke sistem atau output dari sistem. Perancangan Basis Data Perancangan basis data yang dibuat mempunyai tujuan untuk mendefinisikan isi atau struktur dari field yang berbentuk suatu sistem output. Entity Relation Diagram (ERD) ERD merupakan desain model konseptual database yang memberikan gambaran secara umum kepada pemakai tentang perancangan sistem. Dalam permodelan ERD dilakukan dengan tahapan sebagai berikut

Memilih entity-entity yang disusun dalam database dan menentukan hubungan antar entity yang telah dipilih, Melengkapi atribut-atribut yang sesuai pada entity dan hubungan sehingga diperoleh bentuk tabel normal penuh (tabel-tabel ternormalisasi). ERD perancangan sistem gambar 3.5 dibawah ini :

\section{Relasi Antar Tabel}

Relasi antar tabel merupakan desain model konseptualdatabase yang memberikan gambaran secara umum kepada pemakai tentang perancangan sistem. Desain ini menggambarkan hubungan antara tabel yang satu dengan tabel yang lain, dalam satu kesatuan database. Relasi antar tabel dapat dilihat pada gambar 3.6 dibawah ini :

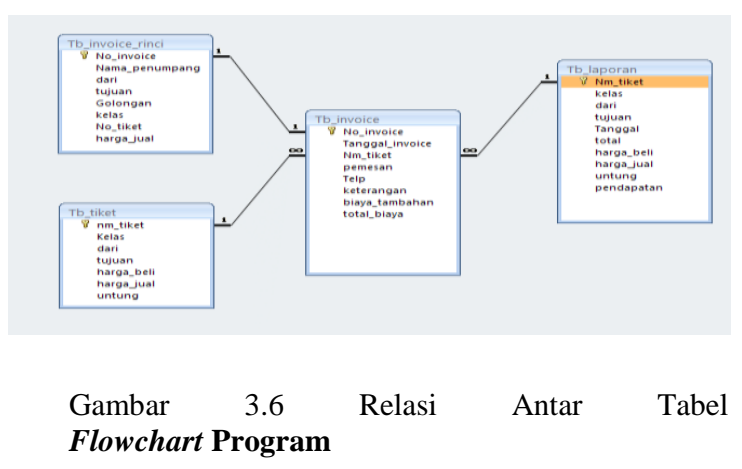

Logika perancangan input dan output sistem komputerisasi Sistem pengolahan data pemesanan tiket akan lebih jelas apabila disajikan dalam bentuk Flowchart Program yang dapat menjelaskan setiap pengolahan data yang terjadi pada sistem.

\section{Rancangan Output Invoice Tiket}

Output Invoice Tiket merupakan rancangan untuk tanda bukti penerimaan pemesanan tiket. 


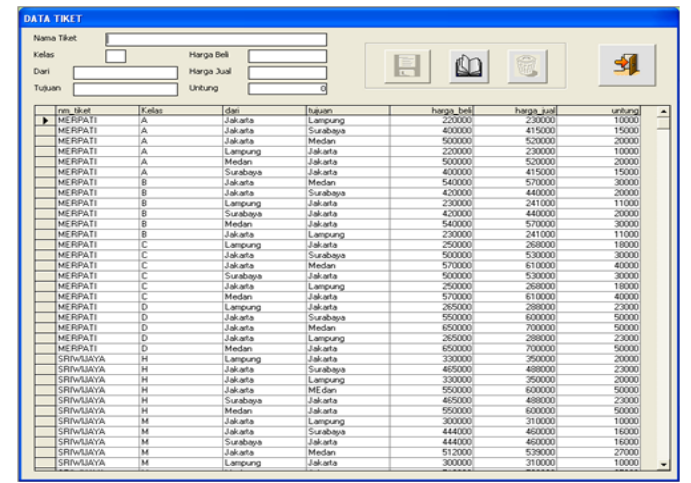

Gambar 3.18 Rancangan Output Invoice

\section{Rancangan Output Laporan Penjualan Tiket}

Output Invoice Tiket merupakan rekapah hasil dari transaksi-transaksi pembuatan invoice yang terjadi yang dijadikan laporan kepada Manager.

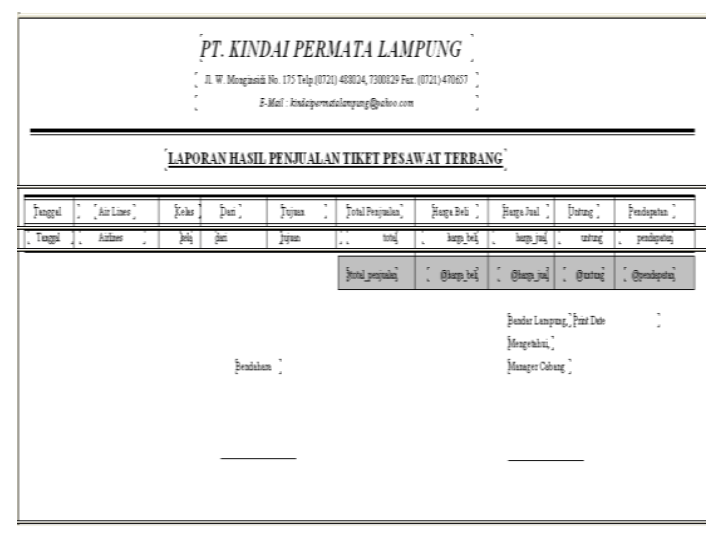

Gambar 3.19 Rancangan OutputLaporan Penjualan Tiket

\section{IMPLEMENTASI DAN PEMBAHASAN}

Implementasi Program

$\mathrm{Bab}$ ini akan menjelaskan tentang pembuatan program Pengolahan Data Pemesanan Tiket beserta bagaimana program ini bekerja, dengan memberikan contoh tampilan form-nya. Implementasi merupakan tahap dimana sistem siap dioperasikan pada tahap sebenarnya, sehingga akan diketahui apakah sistem yang dibuat benar-benar dapat menghasilkan tujuan yang diinginkan.

\section{Form Login}

Form ini adalah hak akses pertama sebelum masuk program induk. Adapun tampilan formlogin seperti berikut :

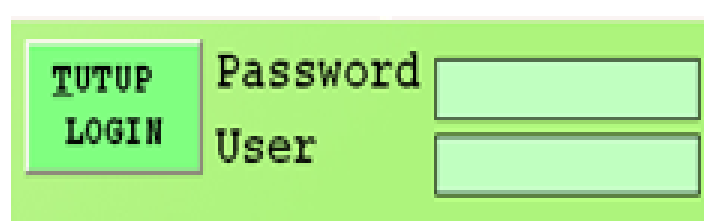

Gambar 4.1 Tampilan Form Login

Tampilan Menu Utama

Form menu utama menampilkan daftar pilihan menu.

\section{Form Data Tiket}

Form Data Tiket dipergunakan untuk merekam data Tiket yang ingin didaftarkan. Data tersebut berupa nama tiket, kelas, dari, tujuan, harga beli, harga jual, untung. form entry data Tiket diperlihatkan pada gambar 4.3.

Form Data Transaksi Penerimaan Invoic Form ini berfungsi untuk melakukan transaksi invoice pesanan tiket oleh pelanggan. Tiket dapat disesuaikan dengan golongan, kelas serta tujuan berangkat

Bentuk tampilan dari form Data Transaksi Penerimaan Invoice dapat dilihatkan pada gambar 4.4 .

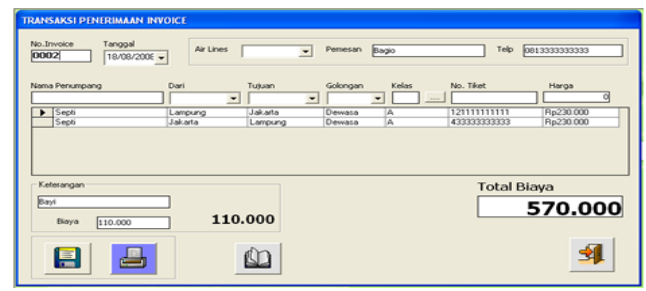

\section{Gambar 4.4 Form Data Transaksi Penerimaan} Invoice

\section{Data Laporan Transaksi}

Data Laporan Transaksi Hasil Penjualan Tiket merekap dengan nomor tanggal invoice yang terjadi.

Tampilan dari form Laporan Transaksi Hasil Penjualan Tiket diperlihatkan seperti pada gambar 4.5 . 


\section{Penjualan Tiket}

\section{Cetakan Invoice}

Output yang dihasilkan dalam Transaksi Invoice .

Bentuk tampilannya sebagai berikut:

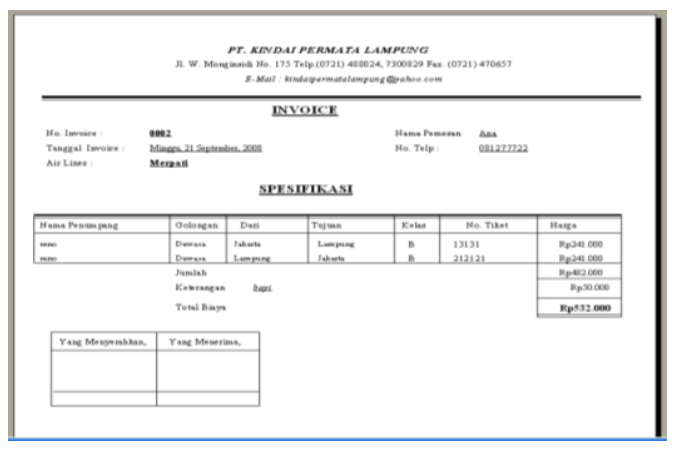

Gambar 4.6 Invoice Pemesanan Tiket

Cetakan Laporan Penjualan Tiket Pesawat Terbang

Output yang dihasilkan dalam Laporan Penjualan tiket. Bentuk tampilannya adalah sebagai berikut:

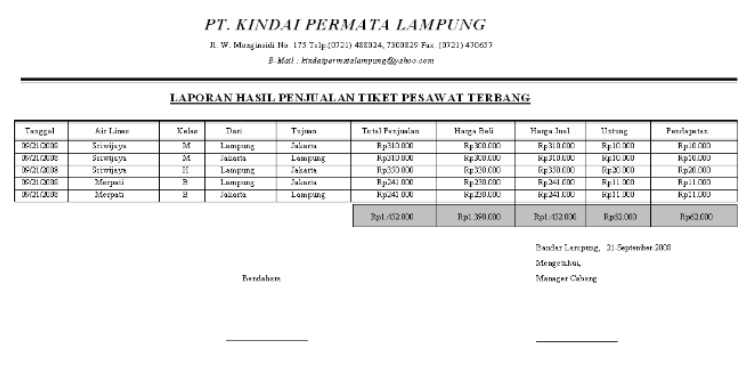

Gambar 4.7 Tampilan Laporan Penjualan Tiket

\section{Cetakan Laporan Rincian Pemesan Tiket Pesawat Terbang}

Output yang dihasilkan dalam Laporan Rincian Pemesan Tiket. Bentuk tampilannya adalah sebagai berikut:

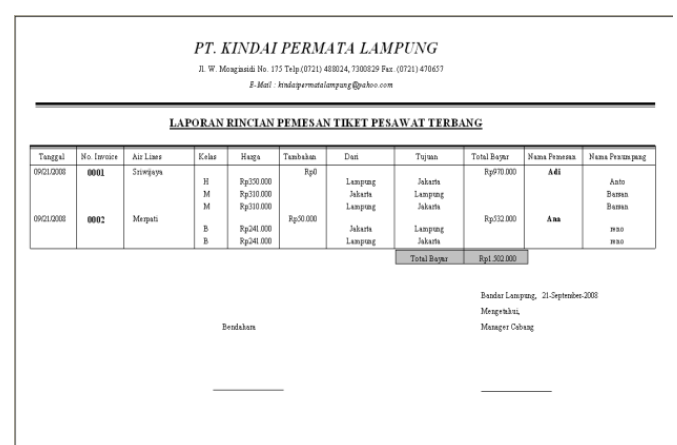

Gambar 4.8 Tampilan Laporan Rincian Pemesan Tiket

\section{SIMPULAN DAN SARAN \\ Simpulan}

Memperhatikan hasil penelitian yang telah dibuat, maka diperoleh beberapa kesimpulan sebagai berikut:

1. Sistem yang berjalan di Perusahaan PT Kindai Permata Lampungtelah menggunakan aplikasi komputer tapi masih bersifat manual atau disebut semi komputer.

2. Masih ditemukan kesulitan dalam peroses pencarian data hasil transaksi.

3. Laporan masih belum begitu baik dan kurang terperinci.

\section{Saran}

Saran yang diberikan kepada perusahaan adalah:

1. Penulis sangat menyarankan agar untuk kedepannya dapat menerapkan sistem pemesanan tiket yang teraplikasi dengan sistem komputerisasi sehingga semua aktivitas pemesanan tiket yang berjalan dapat lebih baik, rapi, efektif dan efisien.

2. Keamanan data yang diberikan oleh sistem dari rancangan penulis dapat lebih terjamin, dan bentuk laporan dapat memberikan informasi yang lebih jelas dan lebih terperinci.

\section{DAFTAR PUSTAKA}

1. Dadan Umar Daihani, 2001, Komputerisasi Pengambilan Keputusan, PT.Elex Media Komputindo, Jakarta

2. Linda Marlinda, S.Kom, 2004, Sistem Basis Data, Andi Offset, Yogyakarta

3. Jogiyanto, 2000, Analisa dan Desain Sistem Informasi, Andi Offset, Yogyakarya.

4. Team STMIK Teknokrat 2006, Buku Panduan Pelaksanaan dan PenulisanSkripsi, Perguruan Tinggi Teknokrat Bandar Lampung.

5. Team, 2007, Company Profile PT Kindai Travel, Bandarlampung.

6. Yuswanto,2003, Pemograman DasarMicrosoft Visual Basic 6.0, Prestasi Pustaka Publishier, Surabaya. 